\title{
The Oxidation of Lactic Acid by Mycobacterium phlei
}

\author{
By N. L. EDSON (Travis Research Fellow), Travis and Biochemical Laboratories, Medical School, \\ University of Otago, New Zealand
}

(Received 27 August 1946)

Although lactic acid is utilized completely during the cultivation of Mycobacterium phlei (Stephenson \& Whetham, 1922), it is oxidized incompletely by 'resting cells' (Edson \& Hunter, 1947). Extracts of crushed cells and acetone-dried preparations, which retain power to oxidize lactate, lose the ability to oxidize pyruvate and acetate. Since an acetone powder will yield a soluble enzyme, this preparation has provided means of studying the mechanism of lactic acid breakdown.

\section{METHODS}

Manometric measurements. Oxygen uptake and $\mathrm{CO}_{2}$ production were determined by the standard methods of Warburg. Substrates (acids as neutral sodium salts) were added after equilibration.

Analytical methods. Lactic acid was estimated by the method of Friedemann \& Graeser (1933). In this procedure blank titrations of volatile bisulphite-binding material obtained from acetone powders never exceeded $0.3 \mathrm{ml}$. $0.005 \mathrm{M}-\mathrm{I}_{2}$. Acetic acid was detected by the lanthanumiodine test (see Edson \& Hunter, 1947); and flavineadenine-dinucleotide by the $d$-amino acid oxidase test of Warburg \& Christian (1938).

Materials. $l(+)$-Lactic acid $\left([\alpha]_{D}^{15^{\circ}}, \mathrm{Zn}\right.$ salt $\left.=-8 \cdot 2^{\circ}\right)$ was obtained from the Pfanstiehl Chemical Co., U.S.A. $d(-)$ Lactic acid $\left([x]_{D}^{15^{\circ}}, \mathrm{Zn}\right.$ salt $\left.=+8 \cdot 0^{\circ}\right)$ was prepared by resolution of $d l$-lactic acid (A.R. (British Drug Houses, Ltd.)) according to the morphine method of Irvine (1906). Catalase was crystallized by the method of Sumner \& Dounce (1937) and dissolved in phosphate saline. Cozymase was prepared by the method of Williamson \& Green (1940).

Acetone powder. The preparation and suspension of the powder have been described (Edson \& Hunter, 1947). Acetone-treated bacilli are somewhat altered but retain their acid-fastness.

Preparation of a soluble enzyme. Because other methods of extraction proved unsatisfactory, $6 \cdot 5 \mathrm{~g}$. of dry powder

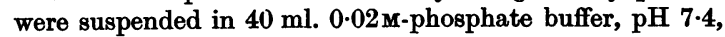
and ground for $4 \mathrm{hr}$. in the wet crushing mill of Booth \& Green (1938). The gross debris was removed by centrifuging at 3500 r.p.m. for $0.5 \mathrm{hr}$. The supernatant liquid was brownish yellow and opalescent. Since high-speed centrifugal apparatus was not available, this fluid was diluted with an equal volume of $0.05 \mathrm{M}$-phosphate buffer and filtered through a bacteriological filter pad (Sterilmat G.S.). The filtrate was perfectly clear, bright yellow and non-fluorescent. It showed the Tyndall phenomenon and gave protein colour tests (biuret, Millon's) and a heat coagulum. The ability of the solution to oxidize lactic acid was not impaired after several weeks storage at $4^{\circ}$.

\section{RESULTS \\ Rate of oxidation of dl-lactate}

Table 1 shows the time course of the oxidation catalyzed by an acetone powder suspended in phosphate buffer. The initial high rate of oxygen consumption diminished progressively in successive $20 \mathrm{~min}$. intervals until the oxidation ceased. In the last interval the increment is only slightly greater than that in the control without substrate. Heated suspensions have no oxygen uptake in the presence or absence of lactate. Table 1 also shows that pyruvate and acetate are not oxidized.

Table 1. Oxygen consumption of acetone powder (Myco. phlei) in the presence of substrates

(16 mg. acetone powder $/ 3 \mathrm{ml}$. 0.06 M-phosphate buffer; $\mathrm{pH} 7.4$; temp. $38^{\circ}$; gas: oxygen.)

\begin{tabular}{|c|c|c|c|c|}
\hline \multirow[b]{2}{*}{$\begin{array}{l}\text { Time } \\
\text { (min.) }\end{array}$} & \multicolumn{4}{|c|}{ Oxygen uptake $(\mu \mathrm{l})}$. \\
\hline & $\begin{array}{c}\text { No } \\
\text { substrate }\end{array}$ & $\begin{array}{c}d l \text {-Lactate, } \\
0.022 \mathrm{M}\end{array}$ & $\begin{array}{c}\text { Pyruvate, } \\
0.02 \mathrm{M}\end{array}$ & $\begin{array}{c}\text { Acetate, } \\
0.02 \mathrm{M}\end{array}$ \\
\hline $\begin{array}{r}20 \\
40 \\
60 \\
80 \\
100 \\
120\end{array}$ & $\begin{array}{l}18 \\
37 \\
55 \\
71 \\
85 \\
96\end{array}$ & $\begin{array}{l}380 \\
665 \\
799 \\
854 \\
874 \\
890\end{array}$ & $\begin{array}{l}17 \\
34 \\
51 \\
67 \\
80 \\
93\end{array}$ & $\begin{array}{l}\mathbf{1 7} \\
\mathbf{3 6} \\
\mathbf{5 4} \\
\mathbf{6 9} \\
\mathbf{8 3} \\
\mathbf{9 4}\end{array}$ \\
\hline
\end{tabular}

Spontaneous oxygen consumption in the controls is reduced by all the inhibitors used (Table 2); but the 'extra' oxygen uptake due to $d l$-lactate is not affected significantly by $\mathrm{HCN}, \mathrm{NaF}$ or arsenite $(0.01 \mathrm{M})$. Significant inhibitions were obtained with octyl alcohol (slight), $\mathrm{NaN}_{3}$ and stronger arsenite $(0.025 \mathrm{M})$. The insensitiveness of this lactate-oxidizing system to cyanide and its relative insensitiveness to azide distinguish it from lactic dehydrogenases which operate aerobically in conjunction with cytochrome systems, e.g. lactic dehydrogenase of yeast (Ogston \& Green, 1935) and of the Gonococcus (Barron \& Hastings, 1933).

\section{Relationship between oxygen uptake and dis- appearance of lactic acid}

When the extra oxygen consumption ceased, about half the $d l$-lactic acid which was added had disappeared, indicating that the enzyme may be 
Table 2. Effects of inhibitors on the oxidation of lactate

(Medium: $3 \mathrm{ml} .0 .033 \mathrm{M}$-phosphate buffer, $\mathrm{pH} 7.4$; temp. $38^{\circ}$; gas: air. When HCN was used as inhibitor, the $\mathrm{CO}_{2}$ absorbent was a mixture of $\mathrm{KOH}$ and $\mathrm{KCN}$ (Krebs, 1935).)

\begin{tabular}{|c|c|c|}
\hline $\begin{array}{l}\text { Weight of } \\
\text { lried acetone } \\
\text { powder/cup } \\
\text { (mg.) }\end{array}$ & $\begin{array}{c}\operatorname{Time} \theta \\
(\min .)\end{array}$ & Inhibitor \\
\hline $20 \cdot 0$ & 60 & $\begin{array}{l}\mathrm{Nil} \\
\mathrm{NaN}_{8}(0.01 \mathrm{~m}) \\
\text { Octyl alcohol (saturated) }\end{array}$ \\
\hline $33 \cdot 0$ & 70 & $\begin{array}{l}\text { Nil } \\
\text { HCN }(0.01 \mathrm{M}) \\
\text { Arsenite }(0.01 \mathrm{M})\end{array}$ \\
\hline $15 \cdot 8$ & 90 & $\begin{array}{l}\text { Nil } \\
\text { NaF }(0.01 \mathrm{M}) \\
\text { Arsenite }(0.025 \mathrm{M})\end{array}$ \\
\hline
\end{tabular}

\begin{tabular}{|c|c|c|}
\hline \multicolumn{2}{|c|}{ Oxygen uptake $(\mu l)}$. & \multirow[b]{2}{*}{$\begin{array}{c}\text { Inhibition } \\
\text { of 'extra' } \\
\mathrm{O}_{2} \text { uptake } \\
(\%)\end{array}$} \\
\hline $\begin{array}{c}\text { Absence of } \\
\text { lactate }\end{array}$ & $\begin{array}{c}\text { Presence of } \\
\text { dl-lactate } \\
(0.02 \mathrm{M})\end{array}$ & \\
\hline $\begin{array}{l}27 \\
15 \\
12\end{array}$ & $\begin{array}{l}583 \\
392 \\
523\end{array}$ & $\begin{array}{r}\overline{32} \\
8\end{array}$ \\
\hline $\begin{array}{l}66 \\
13 \\
50\end{array}$ & $\begin{array}{l}534 \\
475 \\
530\end{array}$ & $\begin{array}{c}-1 \\
\text { Nil }\end{array}$ \\
\hline $\begin{array}{l}38 \\
22 \\
25\end{array}$ & $\begin{array}{l}468 \\
470 \\
382\end{array}$ & $\begin{array}{l}\overline{\mathrm{Nil}} \\
\mathbf{1 7}\end{array}$ \\
\hline
\end{tabular}

Table 3. Oxidation of dl-lactate by acetone powder (Myco. phlei)

(Medium: $3 \mathrm{ml} .0 .033 \mathrm{M}$-phosphate buffer; $\mathrm{pH} \mathrm{7.4}$; temp. $38^{\circ}$; gas: air. $31.6 \mathrm{mg}$. of acetone powder/cup. Time 80 min.)

\begin{tabular}{|c|c|c|c|c|c|}
\hline $\begin{array}{l}d l \text {-Lactic acid } \\
\text { added } \\
\text { (mg.) }\end{array}$ & $\begin{array}{l}\text { Lactic acid } \\
\text { formed }\end{array}$ & $\begin{array}{l}\text { Lactic acid } \\
\text { disappearing } \\
\text { (mg.) }\end{array}$ & $\underset{(\mu \mathrm{l} .)}{\text { Oxygen uptake }}$ & $\begin{array}{l}\text { 'Extra' } \mathbf{O}_{\mathbf{2}} \\
\text { consumed } \\
\quad(\mu \mathrm{l} .)\end{array}$ & $\begin{array}{c}\text { mmol. } \mathrm{O}_{8} \text { consumed/ } \\
\text { mmol. lactic acid } \\
\text { disappearing }\end{array}$ \\
\hline $\begin{array}{l}\text { Nil } \\
5 \cdot 38\end{array}$ & Nil & $\begin{array}{l}\text { Nil } \\
2 \cdot 47\end{array}$ & $\begin{array}{r}74 \\
635\end{array}$ & $\overline{561}$ & $\overline{0.92}$ \\
\hline
\end{tabular}

(1) The experiment was stopped when the oxygen consumption was almost equal to that of the blank in a $10 \mathrm{~min}$. interval.

(2) With the same suspension, which had been heated in a boiling water-bath for 10 min., there was no oxygen uptake and $5.36 \mathrm{mg}$. of lactic acid were recovered.

Table 4. The oxidation of $\mathrm{l}(+)$ - and $\mathrm{d}(-)$-lactate by acetore powder (Myco. phlei)

\begin{tabular}{|c|c|}
\hline $\begin{array}{c}\text { Weight of } \\
\text { dried } \\
\text { acetone } \\
\text { powder/cup } \\
\text { (mg.) }\end{array}$ & $\underset{\text { (min.) }}{\text { Time }}$ \\
\hline $\begin{array}{l}28 \cdot 3 \\
28 \cdot 3 \\
28 \cdot 3\end{array}$ & $\begin{array}{l}130 \\
130 \\
130\end{array}$ \\
\hline $\begin{array}{l}18 \cdot 6 \\
18 \cdot 6\end{array}$ & $\begin{array}{l}120 \\
120\end{array}$ \\
\hline
\end{tabular}

(Medium: $3 \mathrm{ml}$. 0.033 M-phosphate buffer; pH 7·4; temp. $3^{\circ}$; gas: air.)

(1) The experiments were stopped when the oxygen consumption was almost equal to that of the blank in a $10 \mathrm{~min}$. interval.

(2) $d($-)-Lactic acid was recovered completely (4.42 mg.).

specific for one optical isomer (Table 3). The volume of oxygen consumed agrees (within experimental limits) with the theoretical requirements of the ratio, $1 \mathrm{mmol} . \mathrm{O}_{2} / 1 \mathrm{mmol}$. lactic acid. Control experiments have shown that the acetone powder does not form lactic acid spontaneously.

\section{Stereochemical specificity of lactic acid oxidation}

Simultaneous measurements of oxygen consumption and lactic acid disappearance show that the enzyme of acetone powder is entirely specific for the oxidation of $l(+)$-lactic acid (Table 4). The viable cells of $M y c o$. phlei are, however, capable of oxidizing both stereoisomers (Table ${ }^{-5}$ ). In this case the rate

\section{Table 5. Oxidation of $\mathrm{l}(+)$ - and $\mathrm{d}(-)$-lactate} by viable organisms (Myco. phlei)

(Medium: $3 \mathrm{ml}$. 0.033 M-phosphate buffer; $\mathrm{pH} 7 \cdot 4$; temp. $38^{\circ}$; gas: air; bacteria $\equiv 14.2 \mathrm{mg}$. dry wt./cup.)

$\begin{array}{lc} & \begin{array}{c}\text { Oxygen uptake } \\ 1 \mathrm{hr} . \\ \multicolumn{1}{c}{\text { Substrate }}\end{array} \\ \text { Nil } & 93 \\ \text { dl-Lactate }(0.02 \mathrm{M}) & 93 \\ l \text { - }+ \text {-Lactate }(0.01 \mathrm{M}) & 289 \\ d(-) \text {-Lactate }(0.01 \mathrm{M}) & 133 \\ \text { Acetate }(0 \cdot 01 \mathrm{M}) & 158 \\ \text { Pyruvate }(0.01 \mathrm{M}) & 159\end{array}$


of oxidation of $l(+)$-lactate is nearly five times as fast as that of the $d(-)$-isomer, if it be assumed that the endogenous respiration is unaffected by the metabolism of the substrate. Both acetate and pyruvate are oxidized by the viable suspension at a much slower rate than $l(+)$-lactate.

The data of Table 4 also show that the oxidation of $1 \mathrm{mmol}$. of $l(+)$-lactic acid consumes approximately $1 \mathrm{mmol}$. of oxygen. The deficit is due in part to formation of a trace of pyruvic acid (see below).

\section{Relationship between oxygen uptake and $\mathrm{CO}_{2}$ production}

The $\mathrm{CO}_{2}$ production of an acetone powder suspended in phosphate buffer under aerobic conditions is increased by the presence of lactate, the ratio $\mathrm{CO}_{2} / \mathrm{O}_{2}$ becoming approximately $1 \cdot 0$ (Table 6). This fact and the data of Table 4 permit the reaction between lactic acid and oxygen to be formulated as follows :

$$
\mathrm{CH}_{3} \cdot \mathrm{CHOH} \cdot \mathrm{COOH}+\mathrm{O}_{2}=\mathrm{CH}_{3} \cdot \mathrm{COOH}+\mathrm{CO}_{2}+\mathrm{H}_{2} \mathrm{O} \text {. }
$$

\section{Table 6. Relationship between oxygen con- sumption and $\mathrm{CO}_{2}$ production}

(Method of Warburg \& Yabusoe (1924). $20 \mathrm{mg}$. acetone powder/cup. Medium; $3 \mathrm{ml}$. 0.03 $\mathrm{M}$-phosphate buffer; $\mathrm{pH}$ 7.4; temp $38^{\circ}$; gas: air; time $2 \mathrm{hr}$.)

\begin{tabular}{|c|c|c|c|c|}
\hline Substrate & $\begin{array}{c}\text { Oxygen } \\
\text { uptake } \\
(\mu \mathrm{l} .)\end{array}$ & $\begin{array}{c}\text { Total } \mathrm{CO}_{2} \\
\text { (free }+ \\
\text { bound) } \\
(\mu \mathrm{l} .)\end{array}$ & $\mathrm{CO}_{2} / \mathrm{O}_{2}$ & $\begin{array}{l}\text { 'Extra' } \\
\mathrm{CO}_{2} / \mathrm{O}_{2}\end{array}$ \\
\hline $\begin{array}{l}\text { Nil } \\
\text { dl-Lactate }\end{array}$ & $\begin{array}{r}-70 \\
-592\end{array}$ & $\begin{array}{l}+\quad 34 \\
+570\end{array}$ & $\begin{array}{l}0.49 \\
0.96\end{array}$ & $\overline{1.03}$ \\
\hline
\end{tabular}

\section{Products of oxidation}

Acetic acid. In order to test the validity of the above equation the experiments were performed on a larger scale $(7 \mathrm{ml}$. of buffered suspension containing $48 \mathrm{mg}$. of acetone powder and $22 \mathrm{mg}$. of sodium $d l$-lactate). This suspension was shaken aerobically at $38^{\circ}$ for $4 \mathrm{hr}$., after which it was deproteinized by addition of $1 \mathrm{ml} .7 \%(\mathrm{w} / \mathrm{v})$ metaphosphoric acid and filtered. The filtrate yielded an acid volatile in steam which gave an intense blue coloration in the lanthanum-iodine test. Control experiments in which lactate was omitted yielded traces of steam-volatile acid which gave no colour with the lanthanum-iodine reagents.

Although propionic and acetic acids react alike in the lanthanum-iodine test, the quantitative data exclude the possibility of a significant reduction of lactic acid.

Pyruvic acid. Attempts were made to detect the formation of pyruvic acid during the oxidation of lactic acid both in the presence and absence of arsenite. A trace of pyruvate can usually be found after the oxidation of 2-3 mg. of $l(+)$-lactate, the indication being a faint olive-green colour in the nitroprusside test. No such colour develops in control experiments without lactate.

The formation of a trace of pyruvate is confirmed by the results of micro-Clausen titrations (Clift \& Cook, 1932). Reckoned as pyruvic acid, the bisulphite-binding substance amounts to $0.1 \mathrm{mg}$. or less.

\section{Anaerobic dehydrogenation of lactic acid}

An acetone powder prepared from Myco. phlei reduces methylene blue anaerobically. The reduction time is diminished considerably by addition of $d l$ lactate and pyruvic acid is formed (Table 7).

For the purpose of detecting pyruvic acid the contents of each tube were treated with $0.4 \mathrm{ml}$. $30 \%$ (w/v) trichloroacetic acid and filtered through a Whatman no. 40 paper $(4.25 \mathrm{~cm}$.). The filtrate was shaken to restore full colour to the residual dye and made alkaline with the minimum volume of $\mathrm{NH}_{4} \mathrm{OH}$ (sp.gr. 0.88). Methylene blue was removed by adsorption on a pinch of activated charcoal. The clear, colourless filtrate was suitable for application of the nitroprusside test.

Methylene blue reduction was repeated on a larger scale. Acetone powder $(0.7 \mathrm{~g}$.) was suspended in $500 \mathrm{ml}$. of sterile $0 \cdot 1 \mathrm{M}$-phosphate buffer, $\mathrm{pH} 7 \cdot 4$, in which $1.5 \mathrm{~g}$. methyleneblue chloride had been dissolved. The suspension was distributed equally between two sterile flasks provided with ground-glass stopcocks. $10 \mathrm{ml} .2 \mathrm{~m}$ - $d l$-lactate were added to one; both flasks were then evacuated thoroughly and incubated at $38^{\circ}$ for 6 days. Full aseptic precautions were observed throughout. At the end of the period of incubation the methylene blue was partially decolorized in the flask containing lactate.

The contents of each flask were cleared by addition of $\frac{1}{\mathrm{TO}}$ vol. $30 \%(\mathrm{w} / \mathrm{v})$ trichloroacetic acid and subsequent filtration. The filtrate was made alkaline with $\mathrm{NH}_{4} \mathrm{OH}$ and the residual methylene blue adsorbed on the minimum quantity of charcoal. The nitroprusside test was strongly positive (deep blue) with a $3 \mathrm{ml}$. sample from the flask to which lactate had been added, but negative with the control.

Table 7. Anaerobic reduction of methylene blue by acetone powder from Myco. phlei in presence and absence of lactate

(Each evacuated Thunberg tube contained $12.5 \mathrm{mg}$. acetone powder in $3 \mathrm{ml}$. 0.06 M-phosphate buffer, $\mathrm{pH} \mathrm{7.3}$, and $0.5 \mathrm{ml}$. $0.5 \%$ methylene blue solution; temp. $38^{\circ}$; $0 \cdot 3 \mathrm{ml} .0 \cdot 2 \mathrm{M}-d l$-lactate solution added from hollow stopper at zero time. Conditions were aseptic.)

$\begin{array}{llrc} & \text { Substrate } & \begin{array}{c}\text { Reduction } \\ \text { time } \\ (\text { min.) }\end{array} & \begin{array}{c}\text { Pyruvic } \\ \text { acid } \\ \text { test }\end{array} \\ \text { Unheated suspension } & \begin{array}{l}\text { Nil } \\ \text { dl-Lactate }\end{array} & >\mathbf{3 0 0} & \begin{array}{c}\text { Neg. } \\ \text { Pos. }\end{array} \\ & & & \begin{array}{c}\text { Pos. } \\ \text { (blue ring) }\end{array} \\ \begin{array}{c}\text { Heated suspension } \\ \text { (previously heated }\end{array} & \begin{array}{l}\text { Nil } \\ \text { dl-Lactate }\end{array} & >\mathbf{3 0 0} & \begin{array}{c}\text { Neg. } \\ \text { Neg. }\end{array}\end{array}$


Each filtrate was acidified with $\mathrm{HCl}$ and mixed with $\frac{1}{5}$ vol. of a saturated solution of 2:4-dinitrophenylhydrazine in $2 \mathrm{~N}-\mathrm{HCl}$. A yellow crystalline precipitate developed slowly in the cold in the filtrate which had given a positive nitroprusside test. This was collected by centrifugation, washed first with $0.2 \mathrm{~N}-\mathrm{HCl}$ and then with distilled water, and dried in vacuo (yield $33 \mathrm{mg}$.). The 2:4-dinitrophenylhydrazone of pyruvic acid was recrystallized from hot ethyl acetate. M.p. $215^{\circ}$ (uncorr.).

\section{Anaerobic $\mathrm{CO}_{2}$ formation by acetone powder}

It has been shown that the acetone powder catalyzes the dehydrogenation of lactic acid anaerobically with methylene blue as hydrogen acceptor, and that it does not oxidize added pyruvic acid under aerobic conditions. On this account it is necessary to explain the following facts:-(1) pyruvic acid does not accumulate to any significant extent during aerobic oxidation of lactic acid even in the presence of arsenite; (2) the oxygen consumption is the amount required theoretically for conversion of lactic to acetic acid; and (3) acetic acid has been found.

The dilemma could be resolved if the acetone powder were able to catalyze anaerobic dismutation of pyruvate in the manner described by Krebs (1937). Table 8 shows that acetone powder forms $\mathrm{CO}_{2}$ slowly under anaerobic conditions, but the rate is not affected significantly by addition of pyruvate, and therefore another explanation must be sought.

\section{Table 8. Anaerobic $\mathrm{CO}_{2}$ production by acetone powder from Myco. phlei}

(10 mg. acetone powder/cup. Medium: $2 \mathrm{ml}$. bicarbonate saline $\left(0.9 \% \mathrm{NaCl}-0.025 \mathrm{M}-\mathrm{NaHCO}_{3}\right) ; \mathrm{pH} 7.3$; temp. $38^{\circ}$; gas mixture: $5 \% \mathrm{CO}_{2}+95 \% \mathrm{~N}_{2}$. Phosphorus in the inseal.)

\begin{tabular}{|c|c|}
\hline Substrate & $\begin{array}{l}\mathrm{CO}_{2} \text { formation } \\
\text { in } 2 \mathrm{hr} \text {. } \\
(\mu \mathrm{l} .)\end{array}$ \\
\hline Nil & 27 \\
\hline Arsenite $(0.02 \mathrm{M})$ & 24 \\
\hline Pyruvate $(0.02 \mathrm{M})$ & 33 \\
\hline Pyruvate $(0.02 \mathrm{M})+\operatorname{arsenite}(0.02 \mathrm{M})$ & 32 \\
\hline
\end{tabular}

\section{The possible role of hydrogen peroxide}

The following sequence of events, involving an autoxidizable, heat-labile catalyst $(X)$, is consistent with the over-all equation (1):

$$
\begin{gathered}
\mathrm{CH}_{3} \cdot \mathrm{CHOH} \cdot \mathrm{COOH}+\mathrm{X}=\mathrm{CH}_{3} \cdot \mathrm{CO} \cdot \mathrm{COOH}+\mathrm{XH}_{2}, \\
\quad \mathrm{XH}_{2}+\mathrm{O}_{2}=\mathrm{X}+\mathrm{H}_{2} \mathrm{O}_{2}, \\
\mathrm{CH}_{3} \cdot \mathrm{CO} \cdot \mathrm{COOH}+\mathrm{H}_{2} \mathrm{O}_{2}=\mathrm{CH}_{3} \cdot \mathrm{COOH}+\mathrm{CO}_{2}+\mathrm{H}_{2} \mathrm{O} .
\end{gathered}
$$

Reaction (4), which is quantitative, non-enzymic and almost instantaneous at $38^{\circ}$, was described by Holleman (1904). By means of the sensitive methods of Feigl (1937), it has not been possible to detect accumulation of $\mathrm{H}_{2} \mathrm{O}_{2}$ in aerobic experiments either in presence or absence of lactate. Moreover, the addition of pure catalase does not inhibit the oxidation of lactate by acetone powder (Table 9). It was also found, with the method of Stern (1932), that the acetone powder possessed a low catalase activity (kat. $f=0 \cdot 36$ ).

\section{Table 9. Effect of catalase on the} oxidation of lactate

\section{Acetone powder}

(7.1 mg. acetone powder suspended in $3 \mathrm{ml} .0 .033 \mathrm{M}$-phosphate buffer; $\mathrm{pH} 7 \cdot 4 ;$ temp. $38^{\circ}$; gas: $\mathrm{O}_{2}$. Catalase solution contained $500 \mu \mathrm{g}$. crystalline catalase $/ \mathrm{ml}$.)

$\begin{array}{lcccc}\text { Suspension (ml.) } & \mathbf{3 \cdot 0} & \mathbf{3 \cdot 0} & \mathbf{3 \cdot 0} & \mathbf{3 \cdot 0} \\ \text { Catalase solution (ml.) } & - & \mathbf{0 . 5} & - & 0.5 \\ \text { dl-Lactate (0.2M) (ml.) } & - & - & 0 \cdot 3 & 0 \cdot 3 \\ \text { Distilled water (ml.) } & \mathbf{0 . 8} & \mathbf{0 \cdot 3} & 0.5 & - \\ \mathrm{O}_{2} \text { uptake in } 130 \mathrm{~min} .(\mu \mathrm{l} .) & \mathbf{3 8} & \mathbf{5 0} & \mathbf{6 4 7} & \mathbf{6 5 9}\end{array}$

Soluble enzyme

(Dialyzed preparation dissolved in $0.033 \mathrm{M}$-phosphate buffer; $\mathrm{pH} \mathbf{7 \cdot 4}$; temp. $\mathbf{3 8}^{\circ}$; gas: air. Catalase solution contained $90 \mu$ g. crystalline catalase $/ \mathrm{ml}$.)

Enzyme solution (ml.)

Catalase solution (ml.)

dl-Lactate $(0 \cdot 2 \mathrm{M})(\mathrm{ml}$.)

Distilled water (ml.)

$\mathrm{O}_{2}$ uptake in $130 \mathrm{~min}$. ( $\mu \mathrm{l}$.)

\begin{tabular}{cccc}
1.5 & 1.5 & 1.5 & 1.5 \\
- & 0.2 & - & 0.2 \\
$\overline{0.5}$ & -1.3 & 0.3 & 0.3 \\
\hline 0 & 0 & 308 & 234
\end{tabular}

\section{Soluble lactic enzyme of Myco. phlei}

An extract of acetone powder free from cellular debris (see Methods) was fractionated according to the scheme of Fig. 1, partial separation of the enzyme being effected. The ability of each fraction to oxidize lactic acid is shown in Table 10. It will be seen that the activity of the lactic enzyme is not impaired by dialysis which is prolonged sufficiently to precipitate the bulk of the extracted protein. The active precipitate (fraction $E$ ) dissolved readily in phosphate buffer; the supernatant (fraction $F$ ) contained a small amount of inactive protein.

The original extract $(A)$ gave a precipitate of yellow protein when brought to $\mathrm{pH} \mathbf{4} \cdot 5$, leaving a yellowish supernatant. On re-solution in buffer this precipitate (fraction $B$ ) exhibited little activity. Most of the active protein (fraction $C$ ) was precipitated from the supernatant by $\left(\mathrm{NH}_{4}\right)_{2} \mathrm{SO}_{4}$ at $\mathrm{pH}$ 4.5. The residual protein (fraction $D$ ) was inactive. The operation of precipitating with $\left(\mathrm{NH}_{4}\right)_{2} \mathrm{SO}_{4}$ ( 0.3 saturation) at $\mathrm{pH} 4.5$ was repeated twice with fraction $C$, the final solution in $23 \mathrm{ml}$. of phosphate buffer being pale yellow. At each repetition small amounts of inactive yellow protein were thrown down at $\mathrm{pH} 4.5$ and removed prior to addition of $\left(\mathrm{NH}_{4}\right)_{2} \mathrm{SO}_{4}$. 
Table 10. Oxidation of lactate by fractions of the soluble enzyme preparation from Myco. phlei

(Each manometric cup contained $1 \mathrm{ml}$. protein solution (see Fig. 1) in phosphate buffer; pH 7.4. Substrate: $0.3 \mathrm{ml}$. $0 \cdot 2 \mathrm{M}$-dl-lactate; temp. $38^{\circ}$; gas: air.)

Oxygen uptake in $1 \mathrm{hr} .(\mu \mathrm{l}$.

Original extract $(A)$ 228

Fraction $E$ (dialyzed enzyme) 209

Fraction $C$ (precipitated and dialyzed)

210

Fraction $C$ (twice reprecipitated and dialyzed) 215

Fraction $B$

Fraction $D$

Fraction $F$

Nil

(1) Controls without lactate had no oxygen uptake. (2) Addition of $0.2 \mathrm{ml}$. cozymase solution $(5 \mathrm{mg} . / \mathrm{ml}$.) had no effect on oxygen uptake. spontaneous oxygen consumption. The enzyme did not oxidize $d l$-alanine. Brief exposure to mineral acid ( $\mathrm{pH} \mathrm{2.0)}$ at $0^{\circ}$ caused inactivation.

The behaviour of the original extract $(A)$ and of the several fractions was unaffected by addition of cozymase. It may be noted that the lactic dehydrogenase of Esch. coli is also indifferent to the presence of cozymase (Still, 1941).

Addition of catalase partially inhibited the oxidation of lactate, an effect which was not observed with acetone powder (Table 9).

\section{Occurrence of F.A.D. in acetone powder and in soluble enzyme preparations}

When acetone powder was treated with $\mathrm{N}-\mathrm{HCl}$ at room temperature, a clear yellow extract was

Fig. 1. Fractionation of a soluble enzyme preparation from acetone powder from Myco. phlei. Soluble enzyme preparation $(A)$ (see Methods)

$25 \mathrm{ml}$. sample. Cooled in ice bath and brought to pH 4.5 with $2 \mathrm{~N}-\mathrm{CH}_{3} . \mathrm{COOH}$ and centrifuged

Bright yellow ppt. Redis. Yellowish supernatant + solved in $25 \mathrm{ml}$. buffer

Fraction $B$ solid $\left(\mathrm{NH}_{4}\right)_{2} \mathrm{SO}_{4}(0 \cdot 3$ saturation) at $0^{\circ}$ and centrifuged

\begin{tabular}{c|c} 
Yellowish ppt. Dissolved in & Pale yellow supernatant + \\
$25 \mathrm{ml}$. buffer. Reprecipi- & Rolid $\left(\mathrm{NH}_{4}\right)_{2} \mathrm{SO}_{4}(0 \cdot 6$ satura- \\
tated by dialysis at $4^{\circ}$ and & at $0^{\circ}$ and centrifuged \\
redissolved in $25 \mathrm{ml}$. buffer & \\
Fraction $C$ & \\
& $\begin{array}{l}\text { White ppt. Redissolved in } \\
20 \mathrm{ml} \text { buffer. Reprecipi- } \\
\text { tated by dialysis and dis- } \\
\text { solved in } 20 \text { ml. buffer }\end{array}$
\end{tabular}

$15 \mathrm{ml}$. sample. Dialyzed 14 days against distilled water at $4^{\circ}$ with daily change of water, and centrifuged

\section{Fraction $D$}

Fractions dissolved in 0.1 $\mathrm{m}$-phosphate buffer; pH $7 \cdot 4$.

Table 11. Occurrence of F.A.D. (flavine-adenine-dinucleotide) in extracts of Myco. phlei

$d$-Amino-acid oxidase test. Each cup contained $2 \mathrm{ml}$. solution amino-acid oxidase protein (sheep kidney) in $0 \cdot 1 \mathrm{~m}$ phosphate buffer; pH 7.4; $0.2 \mathrm{ml} .0 .5 \mathrm{M}-d l$-alanine in side-bulb; temp. $38^{\circ}$; gas: air.

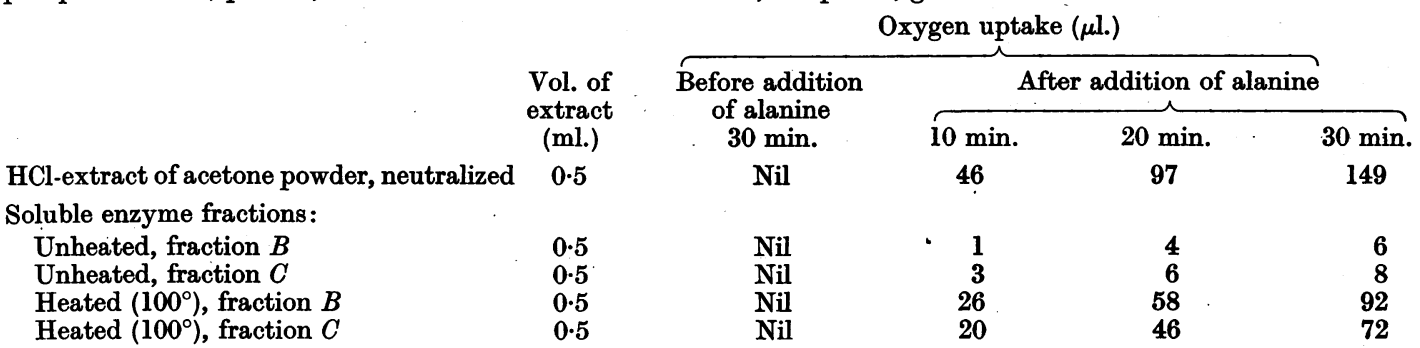

(There was no oxygen uptake in controls from which amino-acid oxidase protein was omitted.)

\section{Action of the soluble enzyme}

Under both aerobic and anaerobic conditions the reactions of fractions $C$ and $E$ with lactic acid were qualitatively identical with those of an acetone powder, but in the absence of lactate there was no obtained. This was bleached by a small amount of $\mathrm{Na}_{2} \mathrm{~S}_{2} \mathrm{O}_{4}$ and the colour restored by shaking with air. After neutralization the extract gave a positive result in the amino-acid oxidase test which is believed to be specific for flavine-adenine-dinucleotide (F.A.D.) (Table 11). 
The presence of free F.A.D. has been demonstrated by the same test in some samples of the soluble enzyme preparation, but not in all. Combined F.A.D., however, was found consistently in the yellow fractions $B, C$ and $E$, which gave positive results in the amino-acid oxidase test only after heating to $100^{\circ}$ (Table 11). The yellow proteins were bleached by $\mathrm{Na}_{2} \mathrm{~S}_{2} \mathrm{O}_{4}$ and the colour restored by air. These facts indicate the presence of flavoprotein.

\section{Influence of peptone on formation of the lactic enzyme}

The ability of viable cells of Myco. phlei and of acetone-dried preparations to oxidize lactic acid was affected by the commercial peptone incorporated in the culture medium. Although the lactic enzyme was always present, the most active preparations were derived from organisms grown on broth containing Witte's peptone (Rostock). The depth of pigmentation appeared to run parallel with enzymic activity.

\section{DISCUSSION .}

Stable enzyme preparations made from $M y c o . p h l e i$ oxidize $l(+)$-lactate to pyruvate anaerobically with methylene blue as hydrogen acceptor; aerobically, these preparations oxidize lactate to acetate and $\mathrm{CO}_{2}$ without the addition of a hydrogen carrier. This distinguishes the enzyme from the lactic dehydrogenase of Esch. coli (Stephenson, 1928; Still, 1941) and of yeast (Dixon \& Zerfas, 1939). Since the enzyme is insensitive to cyanide, it may be concluded that the aerobic oxidation is independent of a cytochrome system. Further, the preparations do not react with added pyruvate.

If it be assumed that pyruvate is an intermediary in the aerobic breakdown of lactate, the phenomena can be explained by a hypothesis of coupled oxidation outlined above in equations (2) to (4). If the assumption is invalid, the mechanism is different from any described hitherto.

Pursuing the assumption that pyruvate is an intermediary in the aerobic process, it is necessary to examine the nature of the heat-labile catalyst which could be either a specific autoxidizable flavoprotein ( $l$-lactic acid oxidase) or a system composed of lactic dehydrogenase, codehydrogenase and an autoxidizable flavoprotein. The presence of a flavoprotein containing F.A.D. in the soluble preparation is consistent with both alternatives. It is to be noted that the bulk of the yellow protein precipitated at $\mathrm{pH} 4.5$ in fraction $B$ does not oxidize lactate.

Since activity is unaffected by dialysis and by repeated precipitation at $\mathrm{pH} 4.5$, it is justifiable to conclude that a coenzyme is either unnecessary or non-dissociable. This distinguishes the lactic enzyme of Myco. phlei from the lactic dehydrogenase of animal tissues (Green \& Brosteaux, 1936), but is consistent with the behaviour of a flavoprotein oxidase.
Theresults permit the following alternative formulations of the dehydrogenation of lactic acid:

(A)

$$
\begin{aligned}
\mathrm{CH}_{3} \cdot \mathrm{CHOH} . \mathrm{COOH}+\mathrm{Co}=\mathrm{CH}_{3} \cdot \mathrm{CO} \cdot \mathrm{COOH}+\mathrm{CoH}_{2} \\
(\mathrm{Lactic} \text { dehydrogenase) } \\
\mathrm{CoH}+F=F \mathrm{H}_{2}+C o \\
F_{2}+\mathrm{O}_{2}=F+\mathrm{H}_{2} \mathrm{O}_{2}, \\
\text { or }(B) \quad \mathrm{CHOH} . \mathrm{COOH}+F^{\prime}=\mathrm{CH}_{3} \cdot \mathrm{CO} \cdot \mathrm{COOH}+F^{\prime} \mathrm{H}_{2} \\
F^{\prime} \mathrm{H}_{2}+\mathrm{O}_{2}=F^{\prime}+\mathrm{H}_{2} \mathrm{O}_{2} .
\end{aligned}
$$

Co represents an unknown codehydrogenase; whilst $F$ and $F^{\prime}$ represent autoxidizable flavoproteins. In both cases the scheme is completed by the spontaneous Holleman reaction:

$$
\mathrm{CH}_{3} \cdot \mathrm{CO} \cdot \mathrm{COOH}+\mathrm{H}_{2} \mathrm{O}_{2}=\mathrm{CH}_{3} \cdot \mathrm{COOH}+\mathrm{CO}_{2}+\mathrm{H}_{2} \mathrm{O} \text {. }
$$

Since the Holleman reaction is rapid, it is unlikely to be a limiting factor in the conversion of lactate to acetate, and so the accumulation of pyruvate or $\mathrm{H}_{2} \mathrm{O}_{2}$ will not be expected. Under aerobic conditions a trace of pyruvate-but not of $\mathrm{H}_{2} \mathrm{O}_{2}$ - has been detected after the action of acetone powder.

The mechanism postulated in $(B)$ is analogous to the known behaviour of a purified $d$-amino-acid oxidase preparation (Negelein \& Brömel, 1939), from which catalase has been removed. An acetone powder from Myco. phlei also possesses very little catalase. The addition of catalase to a suspension of the powder or to the soluble enzyme might be expected. to diminish oxygen uptake and cause the accumulation of pyruvate. When this is done, the prediction is not fulfilled with acetone powder, although it is partially fulfilled with the soluble enzyme (Table 9). If the active surface at which $\mathrm{H}_{2} \mathrm{O}_{2}$ is nascent should be inaccessible to catalase, the main hypothesis is not falsified. A decisive test must await satisfactory purification of the enzyme.

It is evident from earlier observations (Edson \& Hunter, 1947) that lactic acid can be broken down in the manner described in this paper by viable organisms which have been poisoned with HCN or arsenite. Normal cells oxidize pyruvate and acetate more slowly than lactate in reactions which must be partly assimilatory. Nevertheless, the same mechanism of lactic acid breakdown may apply to viable organisms.

\section{SUMMARY}

1. An acetone powder from Myco. phlei contains an enzyme which catalyses the reaction

$\mathrm{CH}_{3} \cdot \mathrm{CHOH} \cdot \mathrm{COOH}+\mathrm{O}_{2}=\mathrm{CH}_{3} \cdot \mathrm{COOH}+\mathrm{CO}_{2}+\mathrm{H}_{2} \mathrm{O}$.

The enzyme is specific for the oxidation of $l(+)$. lactate.

2. Anaerobically, lactate is oxidized to pyruvate.

3. The enzyme has been obtained in soluble form. Its properties are consistent with those of an autoxidizable flavoprotein.

I wish to thank Prof. H. A. Krebs for his kindness in reading the proof. 


\title{
REFERENCES
}

Barron, E. S. G. \& Hastings, A. B. (1933). J. biol. Chem. $100,155$.

Booth, V. H. \& Green, D. E. (1938). Biochem. J. 32, 855. Clift, F. P. \& Cook, R. P. (1932). Biochem. J. 26, 1788.

Dixon, M. \& Zerfas, L. G. (1939). Nature, Land., 143, 557. Edson, N. L. \& Hunter, G. J. E. (1947). Biochem. J. 41, 139. Feigl, F. (1937). Qualitative Analysis by Spot Tests, pp. 21921. Translation by Janet W. Matthews. New York: Nordemann Publishing Co.

Friedemann, T. E. \& Graeser, J. B. (1933). J. biol. Chem. 100, 291.

Green, D. E. \& Brosteaux, J. (1936). Biochem. J. 30, 1489.

Holleman, A. F. (1904). Rec. Trav. chim. Pays-Bas, 23, 169.

Irvine, J. C. (1906). J. chem. Soc. 89, 935.
Krebs, H. A. (1935). Biochem. J. 29, 1620.

Krebs, H. A. (1937). Biochem. J. 31, 661.

Negelein, E. \& Brömel, H. (1939). Biochem. Z. 300, 225.

Ogston, F. J. \& Green, D. E. (1935). Biochem. J. 29, 1983.

Stephenson, M. (1928). Biochem. J. 22, 605.

Stephenson, M. \& Whetham, M. D. (1922). Proc. Roy. Soc. B, 93, 262.

Stern, K. G. (1932). Hoppe-Seyl. Z. 204, 259.

Still, J. L. (1941). Biochem. J. 35, 380.

Sumner, J. B. \& Dounce, A. L. (1937). J. biol. Chem. 121, 417.

Warburg, O. \& Christian, W. (1938). Biochem. Z. 298, 150.

Warburg, O. \& Yabusoe, M. (1924). Biochem. Z. 146, 380.

Williamson, S. \& Green, D. E. (1940). J. biol. Chem. 135, 345.

\section{The Mechanism of Phloridzin Glucosuria}

\author{
By B. SHAPIRO, Laboratory for $\$ Pathological Physiology, The Hebrew University, Jerusalem
}

\section{(Received 2 September 1946)}

Glucose is reabsorbed in the kidney by the proximal tubule (Walker \& Hudson, 1937). Lambrechts (1937) has shown that phloridzin is concentrated in the tubule at the same site. Although the locus of the action of phloridzin in producing glucosuria is thus identified as the proximal tubule, none of the theories which have been put forward explains to entire satisfaction the mechanism of the reabsorption of glucose and the manner of the action of phloridzin on this process. It is generally assumed that glucose is actively reabsorbed in the kidney by a process of phosphorylation. It has been suggested that phloridzin prevents glucose reabsorption by inhibiting glucose phosphorylation (Lundsgaard, 1933; Kalckar, 1936). This view is based mainly on the demonstration that phloriazin can inhibit glucose phosphorylation in vitro, e.g. by kidney slices, mince or extracts. The concentration of phloridzin necessary to inhibit phosphorylation of sugar is, however, definitely higher than the minimum concentration which brings about complete poisoning of reabsorption in the kidney (Lundsgaard, 1935). Kidneys of animals poisoned with phloridzin phosphorylated glucose at the same rate as normal kidneys.

Phloridzin exerts inhibiting effects on a wide variety of enzyme systems. Since such effects had not been observed except at a relatively high concentration of phloridzin, it was considered that they are irrelevant to the role of phloridzin in glucosuria. Re-examination of the validity of this view appeared desirable.
In a systematic test of the action of phloridzin on the different enzymes of carbohydrate desmolysis (Shapiro, 1939), the dehydrogenases of citric and pyruvic acid and certain systems which, by coupling with these dehydrogenases, generate high energy phosphate bonds, have been found to be highly susceptible to phloridzin inhibition. Marked inhibition of the susceptible systems was observed even at concentrations of phloridzin $(0.0002-0.001 \mathrm{M})$ which are too low to affect glucose phosphorylation. It seems probable, therefore, that inhibition of glucose phosphorylation by phloridzin is but one of several secondary results of the action of phloridzin on reactions which generate high-energy phosphate bonds. The present paper summarizes data in proof of this statement. Experiments are also reported to show that the inhibitory effect of phloridzin on highenergy phosphate bond formation is manifested in the kidney of phloridzinized rats in vivo as well as in vitro.

\section{METHODS}

Rat kidneys were cooled on ice, the cortex separated and made into a fine mince with a scissors. When not otherwise stated, the mince $(0 \cdot 3-1.0 \mathrm{~g}$.) was suspended in $5 \mathrm{vol}$. of Krebs's phosphate- or bicarbonate-Ringer solution (Krebs, 1933). Phloridzin $(0.02 \mathrm{M})$ was dissolved in hot water and added to the reaction flasks to obtain the desired final phloridzin concentration.

Glucose was estimated according to Somogyi (1937). Lactic acid was determined by a modification of Friedemann's method according to Lieb \& Zacherl (1932), inorganic phosphate according to Lohmann \& Jendrassik (1926), creatine-phosphate as described by Potter (1945), 